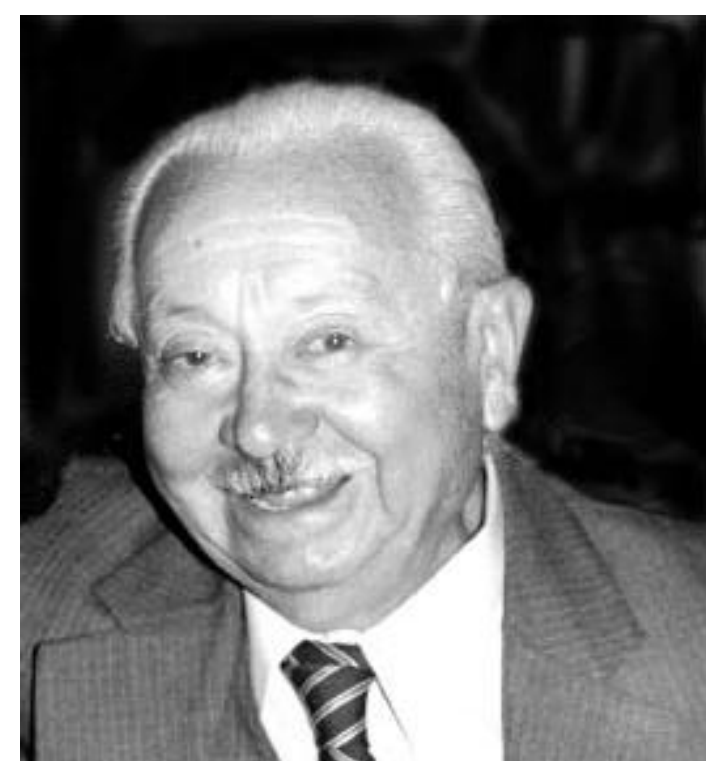

\title{
Doctor Ramón Ferreyra Huerta
}

Con esta página deseamos rendir homenaje a Ramón Ferreyra, profesor Emérito de nuestra Facultad que recientemente ha cumplido 60 años como Doctor en Ciencias Biológicas; momento desde el cual se ha venido dedicando a consolidar el conocimiento botánico en el Perú. Ramón Ferreyra fue el iniciador del Herbario San Marcos, centro de referencia que la actualidad es el más importante del país, él ha venido organizándolo de manera sostenida desde 1948, año en que lo fundó. Durante 20 años dirigió el Museo de Historia Natural de la Universidad Nacional Mayor de San Marcos. Ramón Ferreyra fue uno de los fundadores de la Organización pro Flora Neotrópica (OFN), establecida en 1964, entidad internacional que es la más importante en la difusión de los trabajos taxonómicos de la flora del trópico americano. Por sus cualidades académicas Ramón Ferreyra fue presidente de la OFN entre 1968 y 1970. Es importante destacar su basta producción científica y colecciones botánicas, así como la formación de discípulos que continúan su obra dedicada al conocimiento de la biodiverdad botánica del Perú.

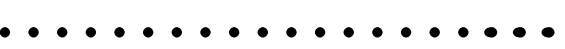

